\title{
New species of Pterostichus subgenus Circinatus (Coleoptera: Carabidae: Pterostichini) from Vietnam
}

\author{
Новые виды Pterostichus подрода Circinatus \\ (Coleoptera: Carabidae: Pterostichini) из Вьетнама
}

\author{
D.N. Fedorenko \\ A.H. Федоренко
}

\begin{abstract}
A.N. Severtsov Institute of ecology and evolution, Leninsky pr. 33, Moscow 119071, Russia. E-mail: dmitri-fedorenko@yandex.ru Институт проблем экологии и эволюции им. А.Н. Северцова, Российская Академия Наук, Ленинский пр-т 33, Москва 119071, Россия.
\end{abstract}

KEY WORDS: Coleoptera, Carabidae, Pterostichus, Circinatus, new species, Vietnam, Oriental region. КЛЮЧЕВЫЕ СЛОВА: Coleoptera, Carabidae, Pterostichus, Circinatus, новый вид, Вьетнам, Ориентальная область.

ABSTRACT. Seven new species of Pterostichus Bonelli, 1810 subgenus Circinatus Sciaky, 1996 are described from Vietnam: P. phiaoc sp.n., P. caobang sp.n., $P$. expolitus sp.n., $P$. phangxipang sp.n., $P$. hoanglien sp.n., $P$. batxatensis sp.n., and P. laocaiensis sp.n. Key to species is provided.

РЕЗЮМЕ. Из Вьетнама описаны 7 новых видов рода Pterostichus Bonelli, 1810 из подрода Circinatus Sciaky, 1996: P. phiaoc sp.n., P. caobang sp.n., $P$. expolitus sp.n., P. phangxipang sp.n., P. hoanglien sp.n., P. batxatensis sp.n., and $P$. laocaiensis sp.n. Составлена таблица для их определения.

\section{Introduction}

The subgenus Circinatus Sciaky, 1996 of the genus Pterostichus Bonelli, 1810 was erected for six species, including new three, from Sichuan and Yunnan provinces, southern China, followed by the next five species described from China [Allegro, Sciaky, 2010] and a comprehensive revision of the subgenus [Shi, Liang, 2015]. The subgenus includes 22 species in China, arranged into four species groups: the agilis-group (six species), the baenningeri-group (nine species), the subtilissimus-group (three species), and the pohnerti-group (four species). In the present paper, we describe seven new species of the subgenus from Vietnam. Material was collected during several field trips and expeditions to highlands of northern Vietnam, sponsored by the Russia-Vietnam Tropical Centre.
Acronyms used are as follows: SIEE - the author's reference collection at A.N. Severtsov Institute of Ecology \& Evolution, Russian Academy of Sciences, Moscow; ZMMU — Zoological Museum of the Moscow State University.

The following parameters were analyzed: maximum body length measured between apices of closed mandibles and apex of elytra (BL); length of elytron, measured from the highest point of basal ridge to apex (EL); maximum width of elytra (EW); width of head across eyes (HW); width of pronotum between apical (PA) or basal (PB) angles; length of pronotum along median line (PL); maximum width of pronotum (PW).

Measurements were taken using an eyepiece micrometer, to two decimal places. The number of specimens measured (n) is only given for the first ratio in the description. All labels are printed. Data on labels of type specimens are in quotes.

\section{Results}

\section{Circinatus Sciaky, 1996}

Type species: Pterostichus pohnerti Jedlička, 1934.

DIAGNOSIS. A subgenus of Pterostichus with the following characters: Body apterous, medium-sized for the genus, more or less shiny black, underside distinctly iridescent, often elytra and sometimes also pronotum slightly less so. Head medium-sized, bisetose above eye; terminal palpomeres subfusiform; frontal foveae rather shallow, short and impunctate; mandibles rather narrow and slightly incurved at apices. Pronotum mostly suborbiculate to ovate, with sides and basal angles rounded, and only inner, impunctate, basal fovea in form of a longitudinal, moderately deep to shallow,

How to cite this article: Fedorenko D.N. 2019. New species of Pterostichus subgenus Circinatus (Coleoptera: Carabidae: Pterostichini) from Vietnam // Russian Entomol. J. Vol.28. No.4. P.358-369. doi: 10.15298/ rusentj.28.4.03 
impressed line; disc convex inside rather fine lateral bead. Elytra oblong-oval, with base narrow, humeri widely to completely rounded, humeral angle obtuse, and basal ridge entire; fully striate; intervals subequally wide, with 1-2 discal setae $(\mathrm{d} 2$ or $\mathrm{d} 2+\mathrm{d} 3)$ in stria 2 , parascutellar seta present. Body setation otherwise as for many other Pterostichus: metacoxa bisetose laterally (inner seta missing), metatrochanter with seta, metafemur bisetose; tarsomere 5 mostly glabrous ventrally. Legs slender; meso- and metatarsomeres with outer carinae mostly conspicuous. Prosternal process not beaded, with a fairly thick posterior inclination. Abdominal sternite VII either smooth in sexes or slightly modified in male. Aedeagus with right paramere small.

REDESCRIPTION. Unnecessary, but for species from Vietnam.

Body (Figs 1-7) medium-sized, shiny black. Tibiae, tarsi and antennae red to reddish-brown, antennae becoming slightly paler apicad. Dorsal microsculpture very superficial, isodiametric on head; transverse on pronotum and elytra, consisting of small, moderately wide meshes to dense lines on the former, and of dense transverse lines or very narrow meshes on the latter.

Head fairly small, without neck constriction; eyes medium-sized and moderately convex, genae rather short. Frontal foveae impunctate, shallow and short, parallel just behind clypeus, thence diverging toward and not quite reaching anterior supra-ocular setae. Antennae moderately long, longer in male, reaching or slightly surpassing elytral base by apical 2.5 segments; antennomeres 4-11 pubescent, scape with dorsal seta, pedicel with ventral seta, antennomere 3 with no setae other than verticellate ones.

Mandibles moderately long, narrow and nearly straight, scrobe medially with a short longitudinal sulcus (missing in $P$. caobang sp.n.). Mentum bisetose at base of a more or less bifid median tooth. Submentum subcostate, quadrisetose, with outer setae much shorter than inner ones. Terminal labial palpomere subfusiform, penultimate labial palpomere bisetose.

Pronotum suborbiculate to cordiform, with basal angles mostly very obtuse and rather widely rounded; base distinctly narrower than apex in general; sides neither explanate nor reflexed, with fine lateral bead extended slightly inside base; apical bead entire to widely obliterate at middle. Disc moderately convex, medial line fine, obliterate basally; basal and apical transverse impressions indistinct or the former barely traceable. Out of two basal sulci, mostly inner sulcus only present, running as a fairly long, moderately deep, and impunctate line; sometimes outer sulcus traceable or basal foveae sparsely punctate. Lateral setae $1-2$, with posterolateral seta inserted in basal angle or much in front, or missing.

Elytra elliptic to subovate, with no humeri, sides rounded, and preapical sinuation subtle. Base long (i.e., wide between basal margin and basal ridge) and narrow or very so; a distinct or missing lateral bead (fine ridge) running inside a small to missing humeral tooth; basal ridge straight to convex apicad, humeral angle obtuse. Internal preapical plica welldeveloped. Striae deep impunctate or indistinctly crenulate,
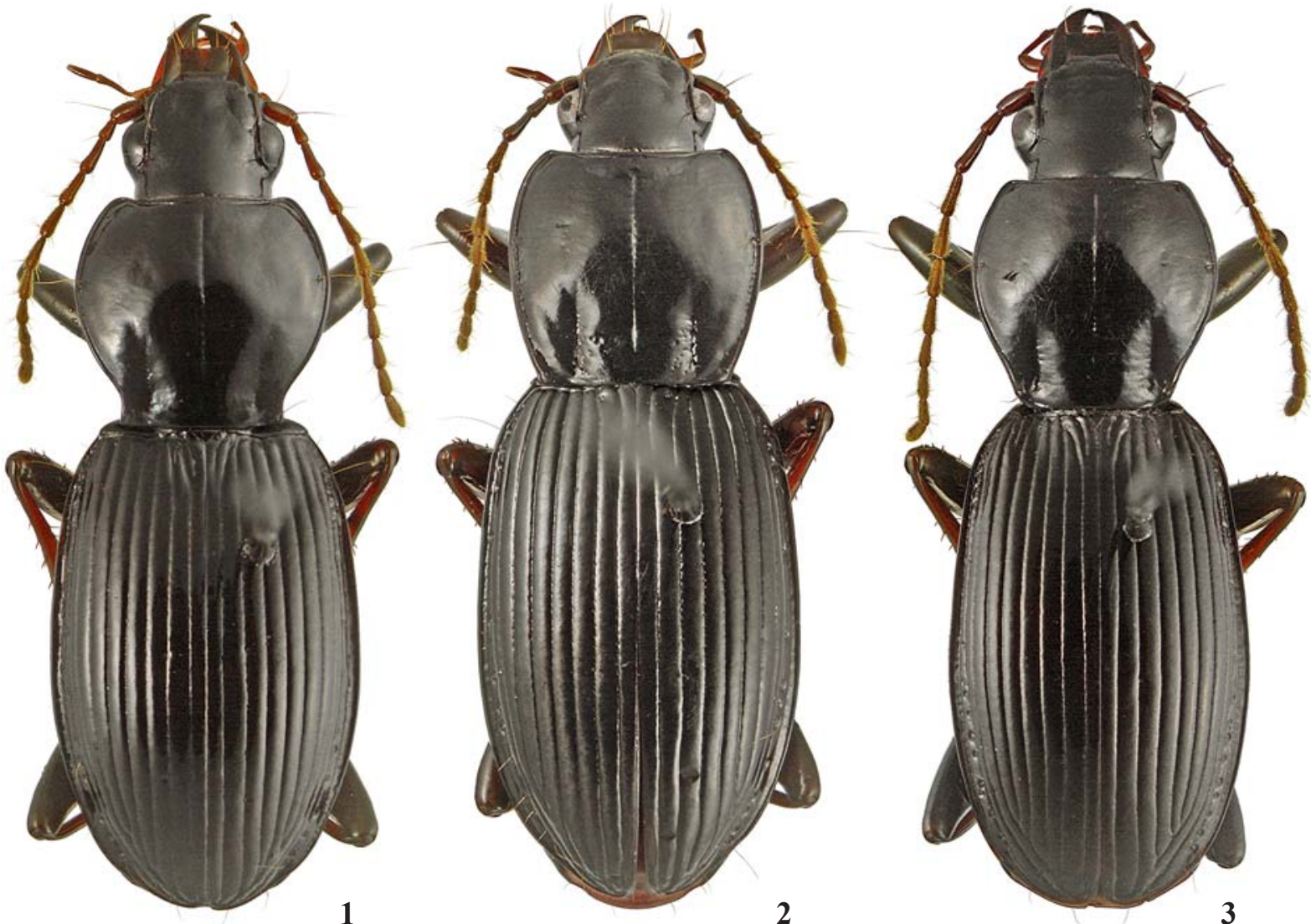

Figs 1-3. Dorsal habitus: 1 - Pterostichus phiaoc sp.n., female paratype; $2-$ P. caobang sp.n., holotype; $3-$ P. expolitus sp.n., holotype.

Рис. 1-3. Габитус дорзально: 1 - Pterostichus phiaoc sp.n., паратип самка; 2 - P. caobang sp.n., голотип; 3 - P. expolitus sp.n., голотип 


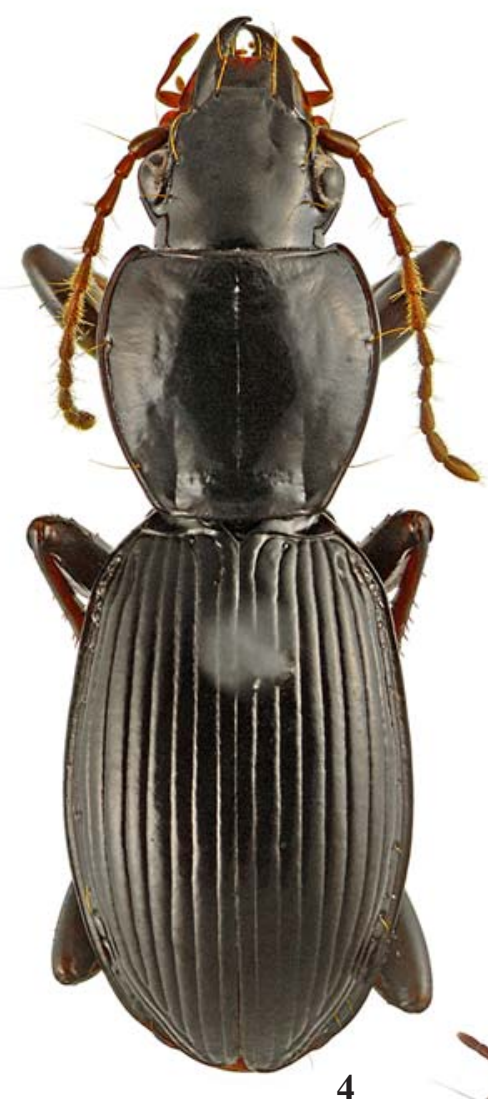

4

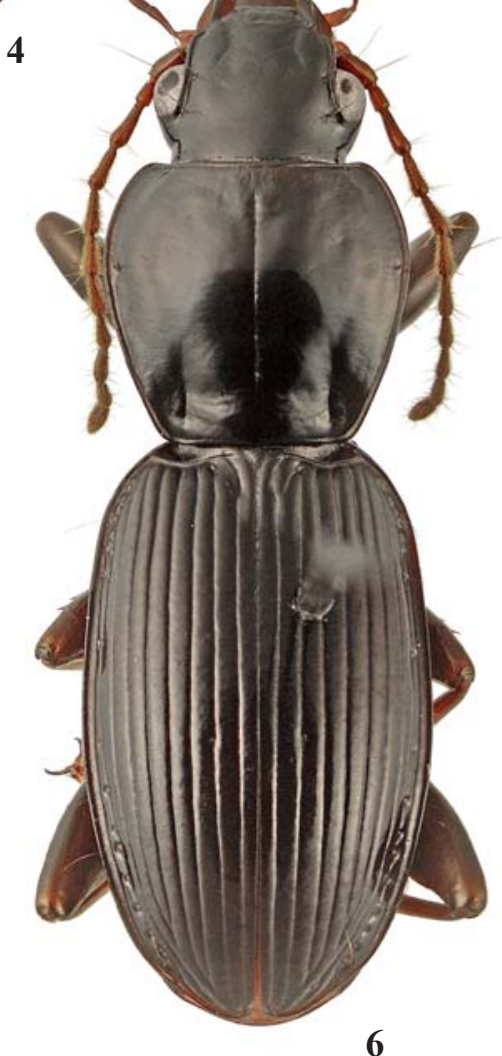

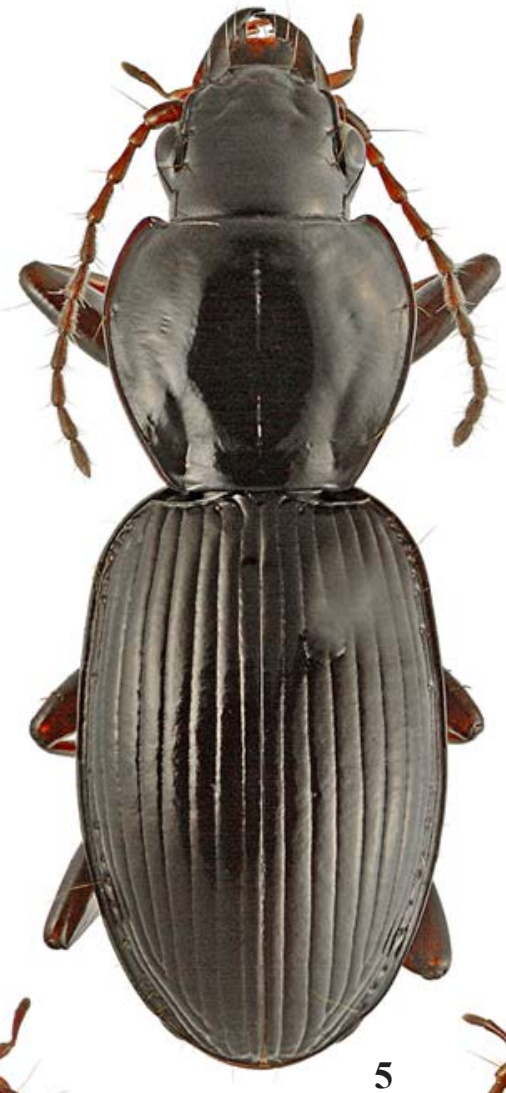

5

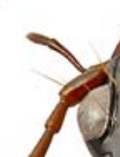

(1)
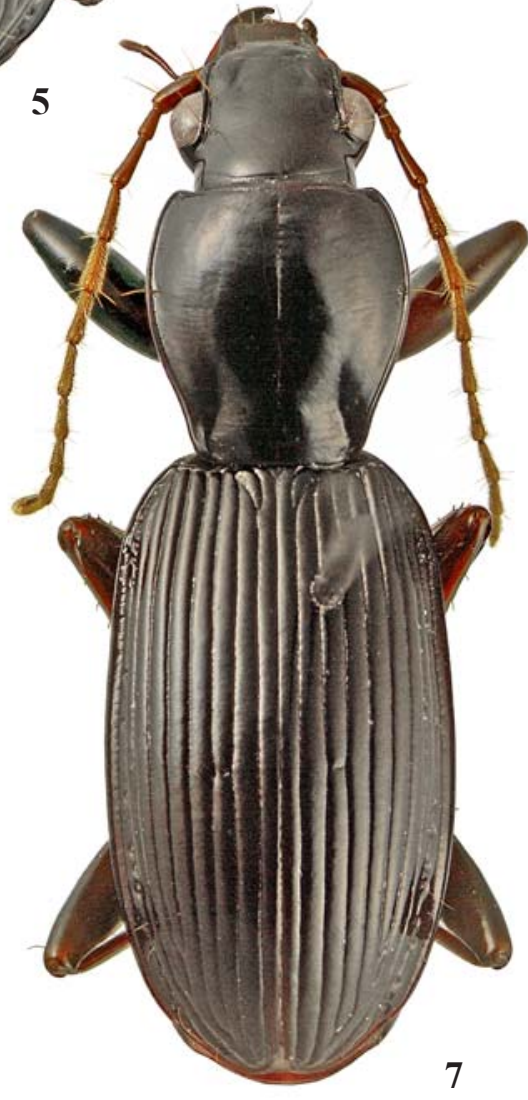

Figs 4-7. Dorsal habitus: 4 - Pterostichus phangxipang sp.n., female paratype; $5-$ P. hoanglien sp.n., female paratype; $6-$ Pterostichus batxatensis sp.n., holotype; $7-$ P. laocaiensis sp.n., male paratype.

Рис. 4-7. Габитус дорзально: 4 - Pterostichus phangxipang sp.n., паратип самка; 5 - P. hoanglien sp.n., паратип самка; 6 Pterostichus batxatensis sp.n., голотип; $7-P$. laocaiensis sp.n., паратип самец. 
1st merged in 8th at sutural angle, 2nd and 7th adjoining 8th just before, 3rd and 4th, as well as 5th and 6th, merged pairwise preapically into a short striole that disappears abruptly. Intervals more or less convex. Reflexed lateral margin narrow; neither additional interval nor carina present outside stria 9. Parascutellar striole entire and deep or missing. Parascutellar seta present, interval 3 with two setae $(\mathrm{d} 2+\mathrm{d} 3)$ adjoining stria 2 or with d2 only. Stria 7 with two preapical setae. Interval 9 with 15-19 umbilical setae (USS) arranged into anterior group (mostly including six setae in basal fourth), and posterior group (mostly nine setae in apical half), with 12 intermediate setae.

Underside entirely smooth or mesepisternum anterolaterally, metepisternum, and abdominal sternites II and III moderately to sparsely punctate. Prosternum with a shallow to distinct medial groove running on basal two thirds; intercoxal

8
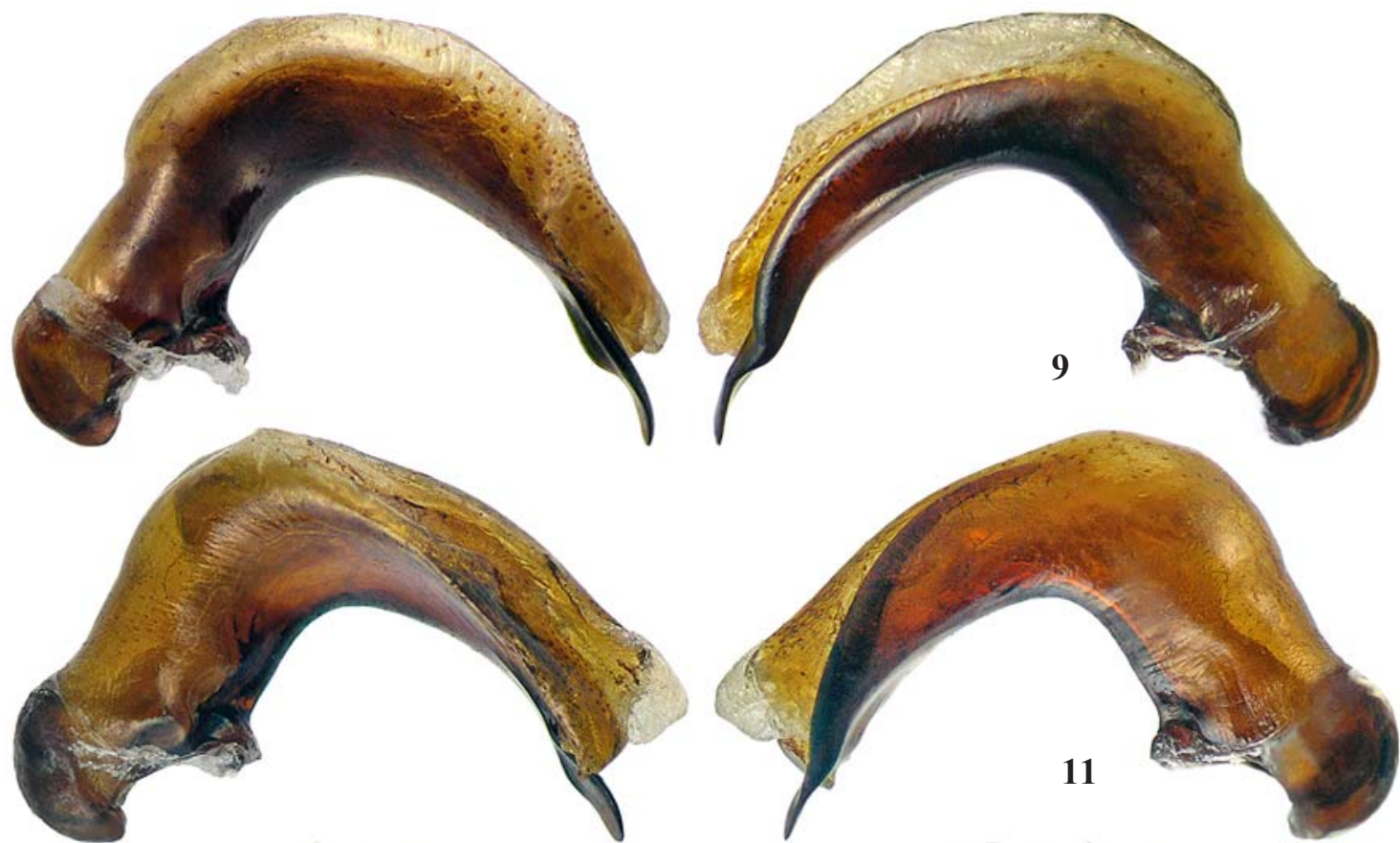

10
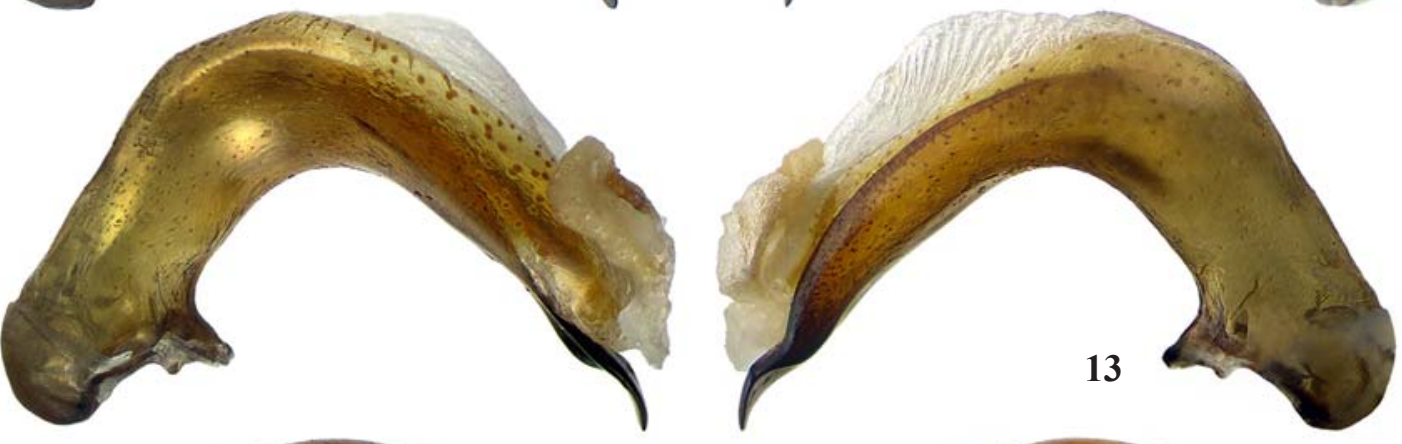

12

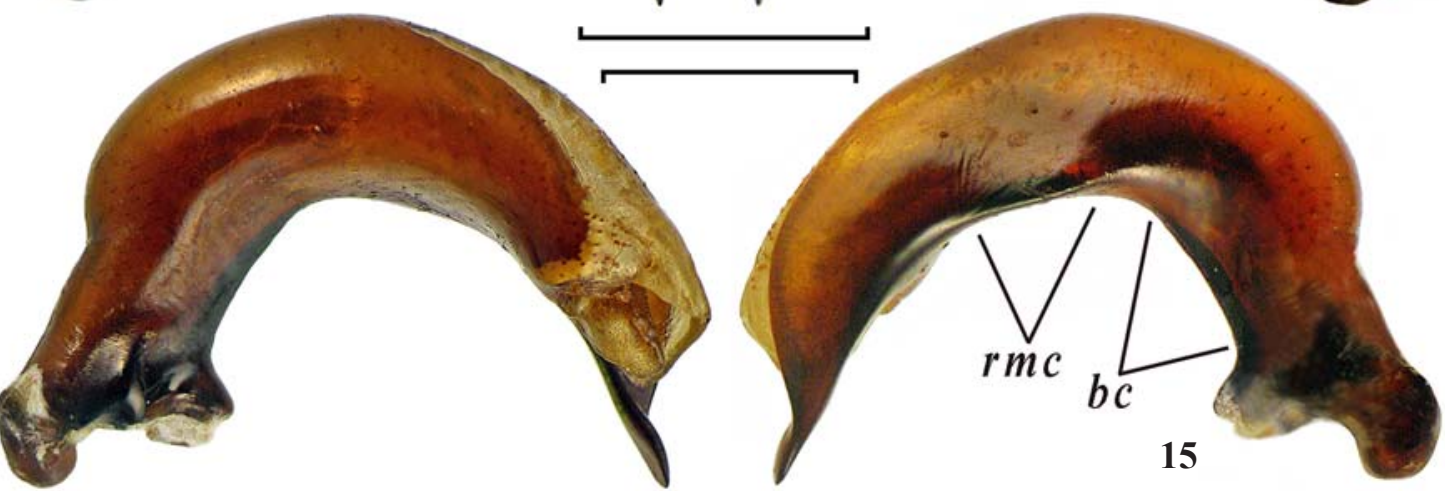

14

Figs 8-15. Median lobe of aedeagus: 8-9 - Pterostichus phangxipang sp.n.; 10-11 - P. hoanglien sp.n.; 12-13 - P. batxatensis sp.n.; 14-15 - P. laocaiensis sp.n.; 8, 10, 12, 14 - left view; 9, 11, 13, 15 - right view. Scale bars: $1 \mathrm{~mm}$.

Рис. 8-15. Средняя доля эдеагуса: 8-9 - Pterostichus phangxipang sp.n.; 10-11 - P. hoanglien sp.n.; 12-13 — P. batxatensis sp.n.; 14-15 - P. laocaiensis sp.n.; 8, 10, 12, 14 - слева; 9, 11, 13, 15 - справа. Масштаб: 1 мм. 
process not beaded, with apical declivity medially constricted and costate to flat. Mesoventrite behind peduncle nearly flat, with a very fine to indistinct median carina and a small precoxal ridge on each side. Metepisternum short, about as long as wide. Abdomen finely beaded on sides.

Legs fairly slender and lightly armed with spiniform setae. Protibiae barely dilated apicad, with two posterolateral apical spinules and one posterior apical spinule. Metatrochanter rounded apically, nearly half as long as metafemur. Meso- and metatarsomeres $1-3$ with a sharp outer (anterior) longitudinal carina and a distinct sulcus just above, or only meso- and metatarsomere 1 with this carina blunt and the sulcus vestigial to missing. Leg setation: profemur posteriorly with three setae, basal, ventromedial, and preapical. Mesofemur with two subequally spaced anteroventral setae and two anterodorsal setae in apical two fifths; mesotibia bisetose laterally, distal seta inserted close to anterior ridge. Metacoxa bisetose (inner seta missing), metatrochanteral seta vestigial or missing; metafemur with two anteroventral (posterior) setae in general, distal seta vestigial to missing; metatibia glabrous laterally. Tarsomeres 1-4 each with one pair of latero-apical setae, tarsomeres 1-2 each with one pair of dorso-apical setae; tarsomere 5 glabrous ventrally.

Aedeagus median lobe (Figs 8-15,31-36) strongly curved distal to basal bulb; right paramere short, subclavate to subtriangular (Figs 21-30). Everted and inflated internal sac bent either ventrad or dorsad.

Female genitalia and reproductive tract. Gonosubcoxite with a few setae along oblique apical margin. Gonocoxite shorter, falcate with a double nematiform seta near apex and three ensiform setae, two ventral (outer) and one dorsal (inner). Spermatheca geniculate, seminal canal short to long, barely sclerotized at base; receptaculum long subcylindric, barely dilated apicad and annulated just apically, or short and clavate, with apex much broader than base.
Secondary sexual differences. In male, abdominal sternite VII not or barely modified, with two setae inserted at a considerable distance from apical margin and often also with apical bead vestigial to obliterate opposite preapical elytral plica or except basally ( $v s$. with four setae close to entire apical bead in female); protarsomeres 1-3 dilated and biserially squamose on ventral side; meso- and metatibia barely wider, with 4-5 smooth tubercles traceable along posteromesal ridge.

DISTRIBUTION. The subgenus has been known [Shi, Liang, 2015] to be widespread in more southern Chinese provinces Sichuan, Yunnan, Chongqing, Guangxi, Hubei, and Guizhou. Discovery of several new species in Vietnam extends the subgenus range southward to at least Vietnamese provinces Lao Cai and Cao Bang.

HABITS AND HABITATS. The members of the genus are closely associated with dead, often not quite fallen, trees in rainforests. Adults of most species were hand collected under rotten tree trunks and their fragments on the ground or under bark at 1600-2100 m altitudes, with some specimens being taken by pitfall trapping.

In a particular locality, at least two of 2-3 sympatric species were found to live syntopically: P. caobang sp.n. and $P$. phiaoc sp.n. in Mt. Phia Oac, $P$. laocaiensis sp.n. and $P$. phangxipang sp.n. in Mt. Phang Xi Pang, $P$. batxatensis sp.n. and $P$. hoanglien sp.n. in the Bat Xat National Park.

COMMENTS. The species from Vietnam match Circinatus groundplan well, except for some features as follows: the body being rather slender in general, the pronotum more slender, and only one discal elytral seta present. Some leg setae, i.e., metatrochanteral seta and distal metafemoral seta, as well as lateral tarsal sulcus in couple with lateral tarsal carina, tend to be reduced. As a result, the setae are usually vestigial or missing, and the tarsal carinae are imperceptible in some species. Besides, all the species from Vietnam share a distinctive internal sac (endophallus groundplan) as follows: when everted and inflated the sac is spiral and directed either apicad

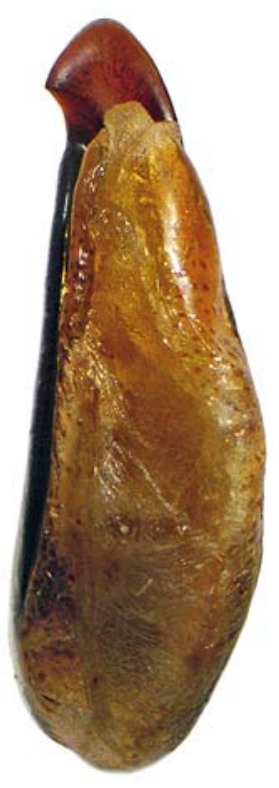

16

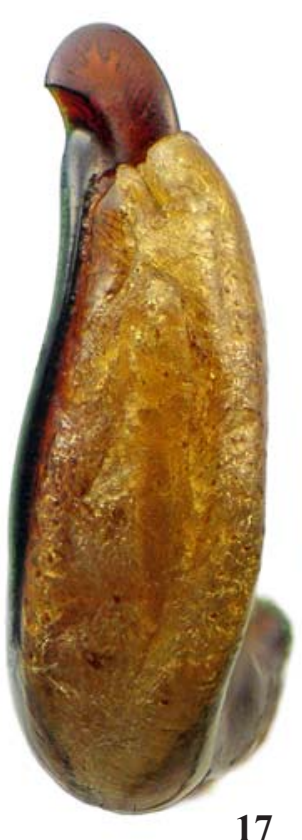

17

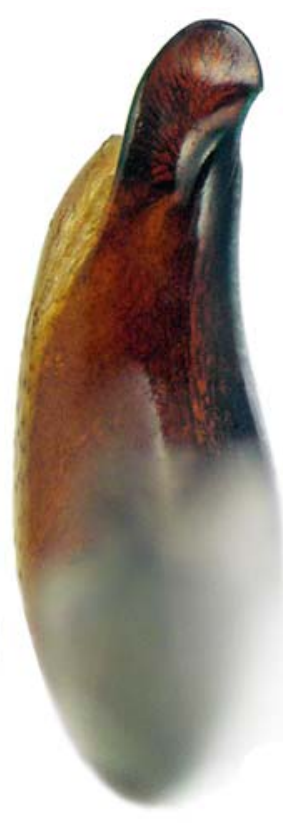

18
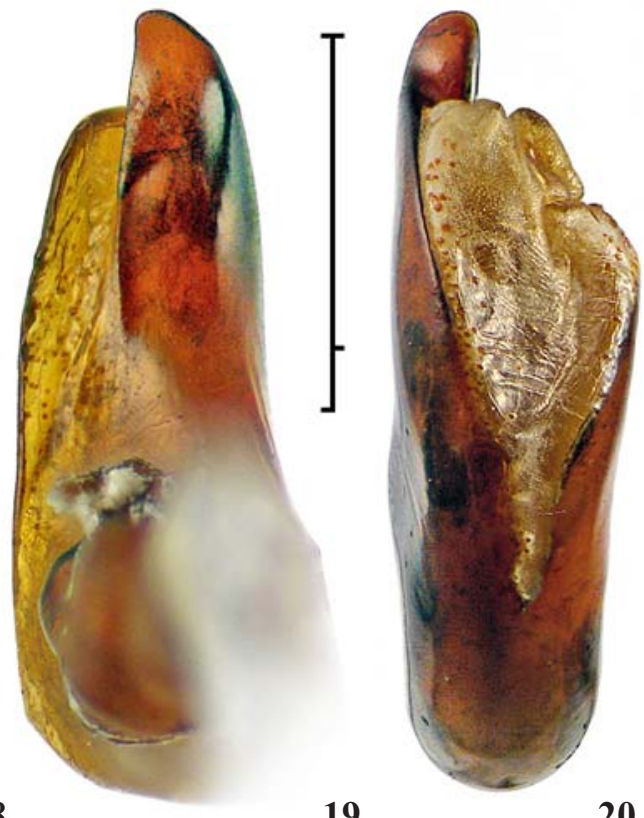

20

Figs 16-20. Median lobe of aedeagus: 16 - Pterostichus phangxipang sp.n.; $17-18-$ P. batxatensis sp.n.; $19-P$. hoanglien sp.n.; 20 - P. laocaiensis sp.n.; 16-17, 20 - dorsal view; 18-19 - ventral view. Scale bar: $1 \mathrm{~mm}$.

Рис. 45-58. Средняя доля эдеагуса: 16 - Pterostichus phangxipang sp.n.; 17-18 - P. batxatensis sp.n.; 19 - P. hoanglien sp.n.; 20 - P. laocaiensis sp.n.; 16-17, 20 - дорзально; 18-19 - вентрально. Масштаб: 1 мм. 
or dorsad. But $P$. phiaoc sp.n. has the internal sac bent ventrad. This character, combined with two discal elytral setae and a quadrisetose pronotum, brings $P$. phiaoc sp.n. closer to the baenningeri species group, whereas the consubgeners from Vietnam belong to a separate species group/lineage.

Four species are here recorded either in central ( $P$. laocaiensis sp.n. and $P$. phangxipang sp.n.) or northwestern part ( $P$. batxatensis sp.n. and $P$. hoanglien sp.n.) of the Hoang Lien mountain ridge, and the sympatric species have been found to live syntopically. Of them, $P$. laocaiensis sp.n. is closer to $P$. batxatensis sp.n. while $P$. phangxipang sp.n. to $P$. hoanglien sp.n., which relationships are supported by two characters, the body being slightly larger ( $v s$. smaller) and the posterolateral pronotal seta missing ( $v s$. present) in the former two and the latter two species, respectively. Unfortunately, there are no available data on distribution patterns of the species discussed to understand whether they interact along the Hoang Lien mountain ridge or not.

\section{Key to SPECies of CirCinatus from Vietnam.}

1(2) Elytron with two discal setae and no basolateral bead. Sides of pronotum deeply sinuate in front of right and sharp basal angles, each side bisetose. - Cao Bang Province 1. P. phiaoc sp.n.

2(1) Elytron with one discal seta near middle; sides of pronotum barely sinuate in front of very obtuse to widely rounded basal angles, each side with 1-2 setae.

3(10) Pronotum with two lateral setae on each side, anterior and posterior.

4(7) Pronotum with posterolateral seta in basal angle and either base slightly wider than apex and basal angles distinct or sides subsinuate in front of rounded basal angles. Meso- and metatarsomeres 1-3 each with a sharp outer lateral sulcus/carina. Pronotal and elytral microsculpture consisting of dense transverse lines.

5(6) Pronotum subquadrate, with distinct basal angles, entire apical bead and two basal sulci on each side; inner sulcus being short, running close to lateral margin and anteriorly merging into lateral groove. Elytron with a distinct humeral tooth extended into basolateral bead; no parascutellar striole. BL $11.4 \mathrm{~mm}$. - Cao Bang Province 2. P. caobang sp.n.

6(5) Pronotum cordate, subsinuate in front of rounded basal angles, with apical bead obliterate medially. Elytron with a long parascutellar striole, nearly indistinct humeral tooth, and basolateral bead missing. BL $15.4 \mathrm{~mm}$. - Cao Bang Province 3. P. expolitus sp.n.

7(4) Pronotal posterolateral seta much in front of basal angle, sides (sub)convex in front of rounded basal angles. Mesoand metatarsi without outer lateral sulcus/carina. Pronotal and elytral microsculpture consisting of slightly transverse or very transverse meshes, respectively.

8(9) Body slender, pronotum barely longer; elytra very narrow basally; mesepisterna in dorsal view traceable just in front of nearly indistinct elytral humeri. Meshes of elytral microsculpture moderately transverse. - Lao Cai Province ....................................... 4. P. phangxipang sp.n.

9(8) Body slightly more robust, pronotum barely shorter; elytra wide basally, with humeri widely rounded and mesepisterna concealed in dorsal view. Meshes of elytral microsculpture transverse and very narrow. - Lao Cai Province

10(3) Pronotal posterolateral seta missing.

11(12) Elytral base beaded laterally. Body more robust due to shorter pronotum and elytra, pronotum barely wider than long, with sides straight behind middle, EL/EW 1.6. Prono- tal and elytral microsculpture consisting of moderately or very transverse meshes, respectively. Only meso- and metatarsomere 1 with a nearly indistinct lateral sulcus. Lao Cai Province . 6. P. batxatensis sp.n.

12(11) Elytral base without lateral bead. Body slender because of pronotum and elytra longer, pronotum barely longer than wide, with sides subsinuate behind middle, EL/EW 1.8. Pronotal and elytral microsculpture consisting of dense transverse lines. Meso- and metatarsomeres 1-3 each with a distinct outer lateral sulcus. - Lao Cai Province .................................. 7. P. laocaiensis sp.n.

\section{Pterostichus phiaoc Fedorenko, sp.n.}

$$
\text { Figs 1, 25, 31-32. }
$$

MATERIAL. Holotype $\sigma^{7}$ (ZMMU) and paratypes, 4 우 (SIEE), labelled: 'N-Vietnam, $40 \mathrm{~km}$ W of Cao Bang, Phia Oac Mt., $22^{\circ} 36^{\prime} 25^{\prime \prime} \mathrm{N} / 105^{\circ} 52^{\prime} 08^{\prime \prime} \mathrm{E}, \mathrm{h} \sim 1650-1700 \mathrm{~m}$, deciduous forest, 311.X.2018, leg. D. Fedorenko'.

DIAGNOSIS. Distinctive from the consubgeners in having pronotum cordate, with sides deeply sinuate in front of right and sharp basal angles, and also in the combination of two discal elytral setae, posterolateral pronotal seta only present and inserted in basal angle, pronotum with lateral bead obliterate before base and two very shallow basal foveae; elytral base with humeral tooth and no lateral bead, mesoand metatarsomeres 1-2 with outer carina and sulcus, and metatrochanteral seta vestigial or missing.

DESCRIPTION. Body (Fig. 1), BL 12.6-13.8 mm. Pronotum and elytra very slightly sericeous, with a trace of iridescence and hardly traceable microsculpture consisting of nearly indistinct, very small, moderately transverse meshes on pronotum while of very dense transverse lines on elytra.

Head: Frontal sulci shallow, subangulate or slightly convex posteromesad. Labrum subsinuate apically.

Pronotum cordate, i.e., nearly orbiculate, but for sides deeply sinuate just in front of and barely diverging towards right and sharp basal angles, PW/PL 1.08-1.11 (mean 1.09, $\mathrm{n}=5), \mathrm{PW} / \mathrm{HW} 1.53-1.58(1.55)$. Base truncate or very gently oblique laterally, as wide as apex, PB/PA 0.96-1.0 (0.98); apex truncate or barely convex, apical angles slightly projecting and blunt. Disc convex and smooth; median line fine, obliterate basally and apically; basal and apical transverse impressions indistinct. Basal sulci shallow, inner sulcus longitudinal, running on basal $2 / 5$, with very few fine punctures; outer one short, smooth and almost imperceptible. Lateral bead fine, obliterate before posterolateral seta, basal bead missing, apical bead shallow or interrupted just medially.

Elytra elliptic, EW/EL 1.57-1.64 (1.60), EW/PW 1.151.20 (1.18), broadest about medially or just behind, rounded on sides, truncate apically combined, with widely rounded humeri, conspicuous humeral tooth and subtle preapical sinuation. Basal ridge subconvex apicad, humeral angle obtuse and sharp; basolateral bead obliterate. Striae deep, minutely to indistinctly punctate at bottom. Intervals slightly convex on disc, convex around. Parascutellar striole entire. Discal setae $\mathrm{d} 2$ and $\mathrm{d} 32 / 5-1 / 2$ or $2 / 3-3 / 5$ distant from base, respectively. USS: $15-17$.

Underside totally smooth, except for some fine punctures on basal two abdominal sternites. Prosternum with a fine yet distinct medial groove; prosternal process in lateral view rectangular and apically rounded; declivity flat near mesothoracic peduncle, with indistinctly beaded lateral edges, subconvex ventrally, rather wide in middle part. Metepisternum barely shorter than wide.

Legs: Meso- and metatarsomeres 1-2 carinate and sulcate laterally, sulcus on mesotarsomere 2 being vestigial. Metatro- 
chanteral seta vestigial or missing, distal metafemoral seta missing.

Aedeagus (Figs 25, 31-32): apex of median lobe rounded in dorsal view, with nearly indistinct rounded tooth on right side just apical to a deep groove which is oblique to the right. Right paramere triangular, well sclerotized on left (inner) side, subsinuate before apex. Everted and inflated internal sac somewhat spiral, bent to the left and ventrad, with two spinose sclerites.

NAME. Toponymic noun, refers to the type locality.

DISTRIBUTION. Known from the type locality only, Mt. Phia Oac, northern Vietnam.

HABITATS AND HABITS. All specimens were hand collected under bark of rotten tree brunches on the ground in a cloudy broad-leaved forest.

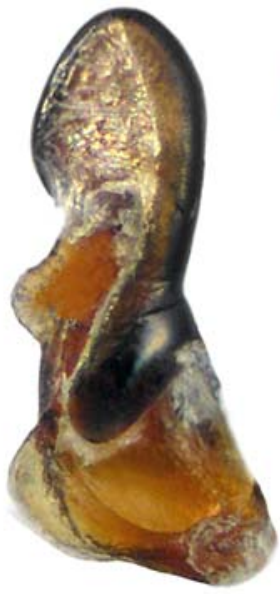

21
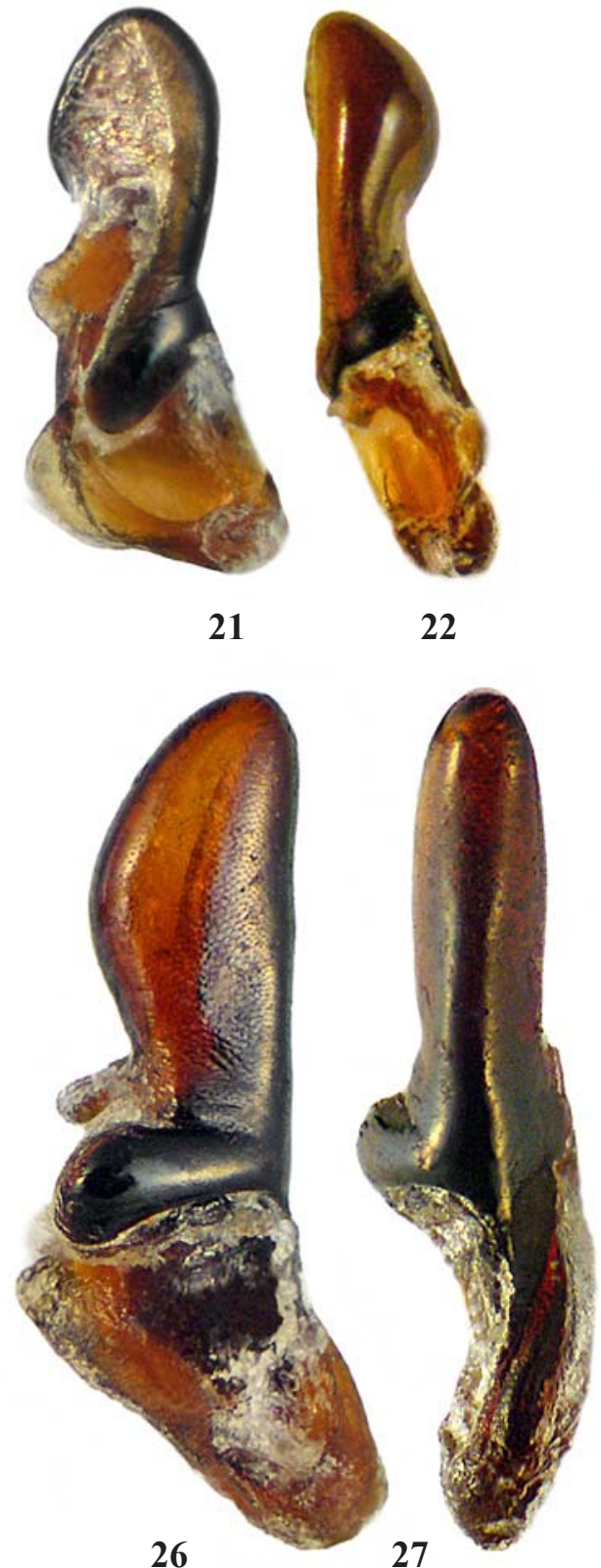

22

\section{Pterostichus caobang Fedorenko, sp.n.}

Fig. 2.

MATERIAL. Holotype + (ZMMU) labelled: 'N-Vietnam, $40 \mathrm{~km}$ W of Cao Bang, Phia Oac Mt., 22 $36^{\prime} 25^{\prime \prime} \mathrm{N} / 105^{\circ} 52^{\prime} 08^{\prime \prime} \mathrm{E}, \mathrm{h} \sim 1650$ $1700 \mathrm{~m}$, deciduous forest, 3-11.X.2018, leg. D. Fedorenko'.

DIAGNOSIS. Distinctive in the combination of pronotum subquadrate and quadrisetose, with inner basal sulcus deep and outer basal sulcus traceable, posterolateral pronotal seta inserted in basal angle, elytron with one discal seta, humeral tooth distinct, parascutellar striole missing, and meso- and metatarsomeres 1-3 with outer carina and sulcus. Besides, mandibular scrobe without longitudinal groove.

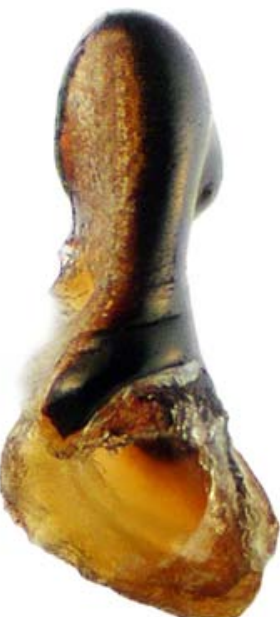

23

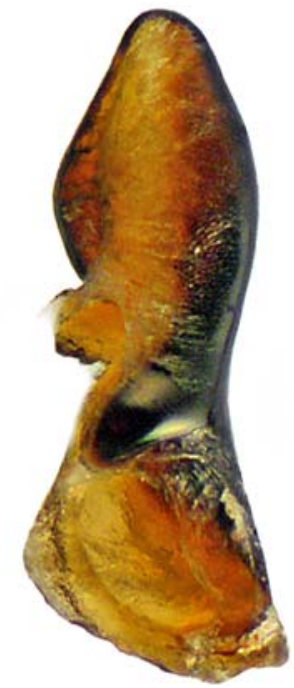

28

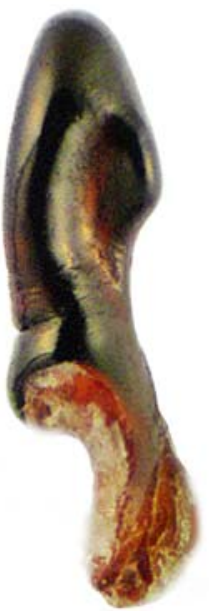

24
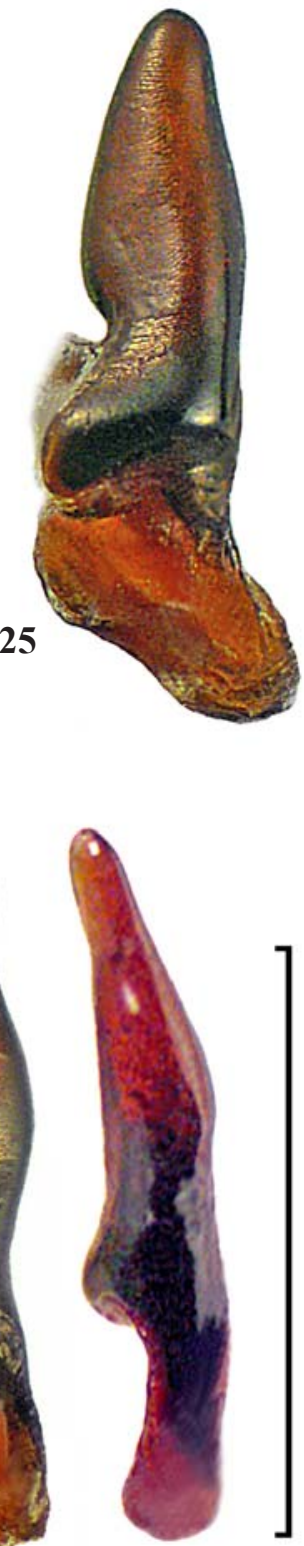

30

Figs 21-30. Right paramere: 21-22 — Pterostichus phangxipang sp.n.; 23-24 - P. batxatensis sp.n.; $25-P$. phiaoc sp.n.; 26-27 P. laocaiensis sp.n.; 28-30 - P. hoanglien sp.n.; 21, 23, 25, 26, 28-29 - left view; 22, 24, 27, 30 - ventral view. Scale bar: 1 mm.

Рис. 21-30. Правая парамера: 21-22 — Pterostichus phangxipang sp.n.; 23-24 - P. batxatensis sp.n.; 25 - P. phiaoc sp.n.; 2627 - P. laocaiensis sp.n.; 28-30 - P. hoanglien sp.n.; 21, 23, 25, 26, 28-29 - слева; 22, 24, 27, 30 — вентрально. Масштаб: 1 мм. 

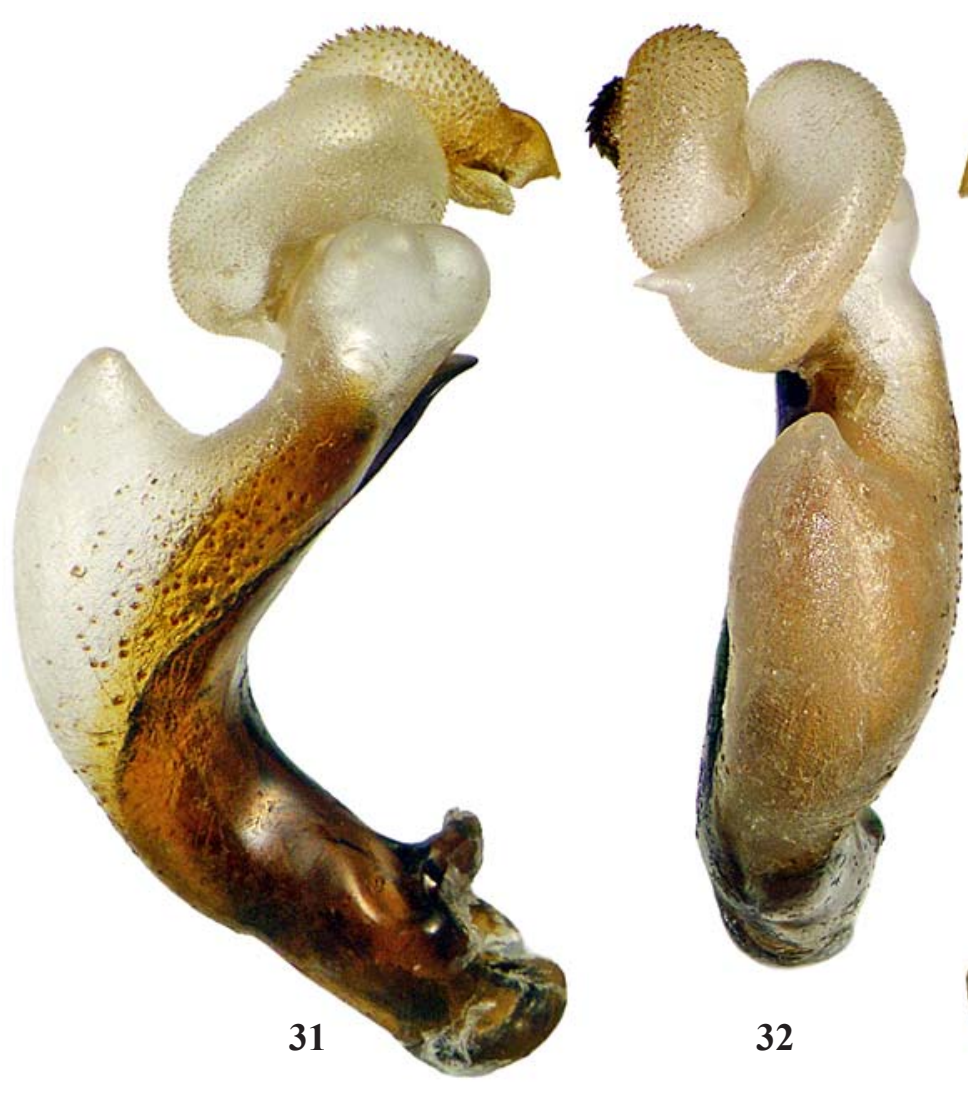

32
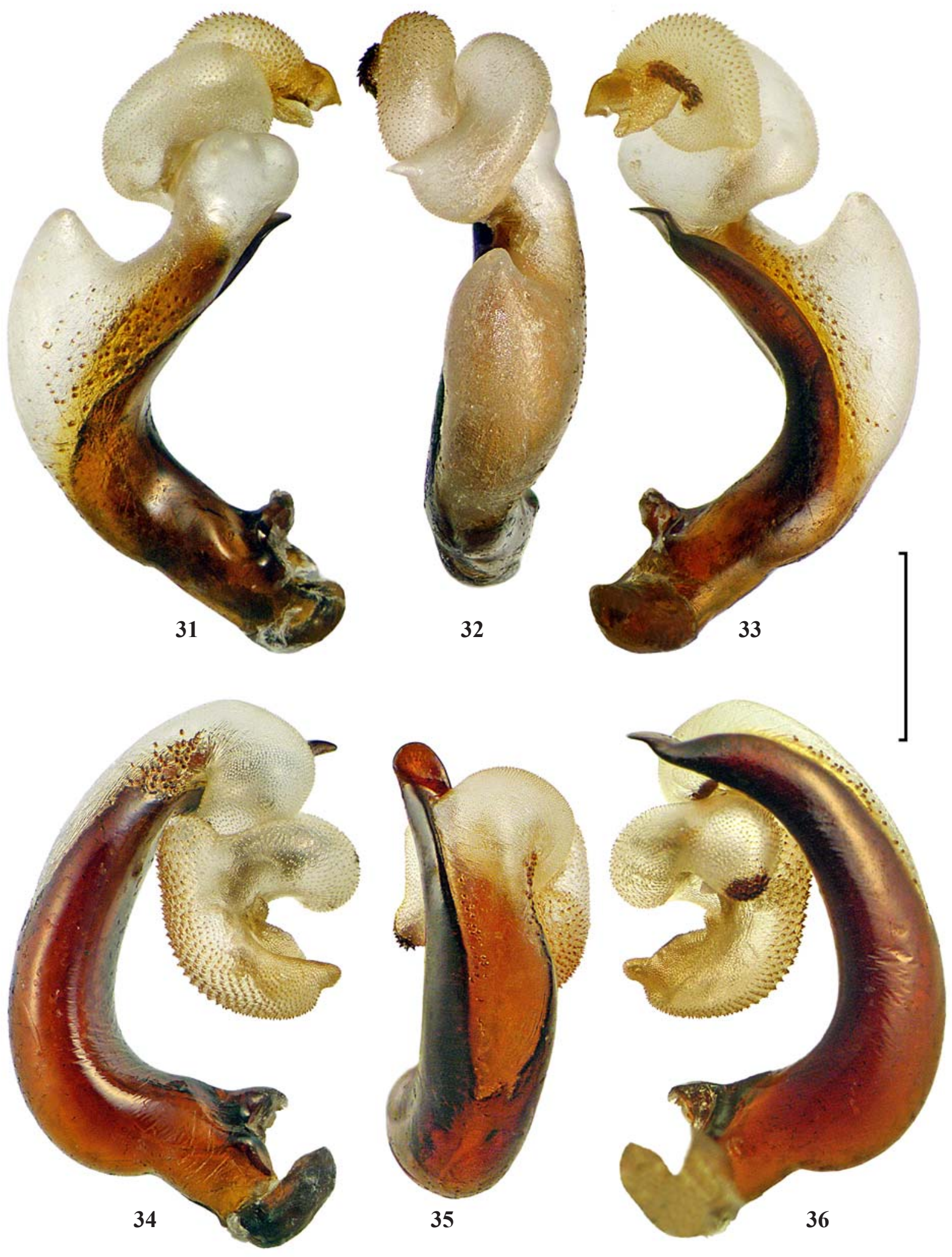

Figs 31-36. Everted and inflated internal sac of aedeagus: 31-33 - Pterostichus phiaoc sp.n.; 34-36 - P. batxatensis sp.n.; 31, 34 left view; 32, 35 - dorsal view; 33, 36 - right view. Scale bar: $1 \mathrm{~mm}$.

Рис. 31-36. Вывернутый и надутый внутренний мешок эдеагуса: 31-33 — Pterostichus phiaoc sp.n.; 34-36 — P. batxatensis sp.n.; 31, 34 - слева; 32, 35 - дорзально; 33, 36 - справа. Масштаб: 1 мм. 
DESCRIPTION. Body (Fig. 2), BL 11.4 mm. Pronotum and elytra slightly sericeous. Pronotal and elytral microsculpture very superficial, consisting of nearly indistinct, very small, moderately transverse meshes on pronotum and of very dense transverse lines on elytra.

Head: Frontal sulci short and shallow, parallel behind clypeus, then diverging towards anterior supra-ocular seta. Labrum truncate apically.

Pronotum rounded on sides, broadest $2 / 5$ from apex, PW/PL 1.10, PW/HW 1.65. Base truncate, PB/PA 1.06, with slightly obtuse basal angles; apex evenly sinuate between sharp and slightly projecting angles. Disc convex and smooth, with hardly traceable basal and apical transverse impressions. Median line fine and slightly crenulate, obliterate basally and apically. Lateral bead fine, reaching posterolateral seta; apical bead fine and entire. Inner basal sulci running parallel on basal $2 / 5$, very deep, finely, and densely to confluently, punctate at bottom, with a few punctures inside, recurved just in front of base to become much shallower yet distinct outer sulci that merge into lateral groove a fourth from base.

Elytra as in previous species, except that basal ridge is nearly straight, humeral tooth larger, basolateral bead distinct, EW/EL 1.58, EW/PW 1.27. Discal setae d2 3/5 distant from apex. USS: 16

Underside: Mes- and metepisternum moderately and densely punctate, abdominal sternites II-IV finely punctate on sides; propleura finely and unevenly punctate along sternopleural sutures. Prosternum with a fairly deep medial groove; prosternal process with a vestigial bead (or perhaps with a secondary knob) on each side just apically, obtuse in lateral view; declivity wide and subconvex.

Legs: Metatrochanteral seta vestigial, distal metafemur bisetose.

NAME. Toponymic noun, refers to Cao Bang Province, Vietnam.

DISTRIBUTION. Known from the type locality only, Mt. Phia Oac, northern Vietnam.

HABITATS AND HABITS. As for the previous species.

\section{Pterostichus expolitus Fedorenko, sp.n.}

Fig. 3.

MATERIAL. Holotype + (ZMMU), labelled: 'N-Vietnam, 40 $\mathrm{km} \mathrm{W}$ of Cao Bang, Phia Oac Mt., E[astern]-slope, h 1600-1800 m, $22^{\circ} 36^{\prime} 27^{\prime \prime} \mathrm{N} / 105^{\circ} 52^{\prime} 0^{\prime \prime} \mathrm{E}$, deciduous forest, 22.V-6.VI.2018, leg. A. Abramov'.

DIAGNOSIS. A slender large-sized species distinctive in having character combination as follows: single discal elytral seta; pronotum cordate and quadrisetose, with posterolateral seta inserted in basal angle, sides subsinuate before rounded basal angles, apical bead widely obliterate at middle, lateral bead extended slightly inside base; inner, deep and impunctate, basal sulcus only present; elytral base with humeral tooth vestigial and no lateral bead; parascutellar striole long; meso- and metatarsomeres 1-3 carinate and sulcate laterally; both metatrochanteral seta and distal femoral seta missing.

DESCRIPTION. Body (Fig. 3), BL 15.4 mm. Pronotum and elytra slightly iridescent, with microsculpture hardly traceable, consisting of dense transverse lines.

Head: Frontal sulci parallel, shallow and short, shortened from behind. Labrum subsinuate apically.

Pronotum quadrisetose, cordate, broadest about 2/5 from apex; sides rounded medially, straight behind apical angles, subsinuate in front of very obtuse and rounded basal angles; PW/PL 1.06, PW/HW 1.49. Base truncate, oblique laterally, barely narrower than apex, PB/PA 0.87 . Apex evenly subsin- uate between slightly projecting, acute and rather sharp, angles; apical bead obliterate in middle third. Disc convex and smooth, basal and apical transverse impressions missing, median line fine, obliterate basally and apically, fine lateral bead extended slightly inside basal angle. Inner basal sulci deep and smooth, running parallel on basal $2 / 5$, not quite reaching base, outer basal sulcus as a very short vestige close to basal angle. Posterolateral seta in basal angle.

Elytra oblong subovate (EW/EL 1.67, EW/PW 1.23), broadest behind middle, with very narrow base, no humeri, and indistinct preapical sinuation; apices rounded and subtruncate combined; sides rounded, diverging and straight from basal $1 / 5$ to $1 / 2$. Base long, with obliterate lateral bead and vestigial humeral tooth; basal ridge nearly straight, humeral angle obtuse and sharp. Striae deep, minutely and sparsely punctate at bottom, lateral groove in basal half with fine and denser punctures. Intervals almost flat, barely more convex at base. Parascutellar striole entire. Discal seta d2 about 3/5 distant from base. USS: $18+19$.

Underside smooth, except mesepisternum rather sparsely punctate within peduncle and abdominal sternite II more densely punctate. Prosternum with a fine yet distinct medial groove; prosternal process obtuse and blunt in lateral view; declivity convex, flat just below mesothoracic peduncle, moderately wide and costate in middle part. Metepisternum as wide as long.

Legs: Meso- and metatarsomeres 1-3 carinate and sulcate laterally. Metatrochanteral seta and distal metafemoral seta missing.

NAME. Refers to very shiny body dorsum.

DISTRIBUTION. Known from the type locality only, Mt. Phia Oac, northern Vietnam.

HABITATS AND HABITS. The only female was taken by pitfall-trapping.

\section{Pterostichus phangxipang Fedorenko, sp.n.} Figs 4, 8-9, 16, 21-22, 37-38.

MATERIAL. Holotype $\sigma^{7}$ (ZMMU) labelled: 'N[orthern] Vietnam, Lao Cai Prov[ince]., Hoang Lien Son Mt. Ridge, env. Fansipan [=Phahg Xi Pang] Mt, Tram Ton, h=1950-2100 [m], 15-30.VII.2007, leg. D. Fedorenko'. Paratypes (SIEE), $0^{\top}, 4+9$, , same data; $20^{\top} 0^{\top},+$, with label: 'N-Vietnam, Lai Chau Prov. env. Sa Pa (Lao Cai Prov.), Hoang Lien Son Natn. Park, $22.34754^{\circ} \mathrm{N} / 103.78049^{\circ} \mathrm{E}, \mathrm{h}=1920$ 2070 m, 19.IV-1.V.2013, A. Prosvirov leg.'; + , labelled: 'N Vietnam, 20 km SW Lao Cai, Sa Pa, h 1800 m, 7.XII.1996, leg. M. Kalyakin'.

DIAGNOSIS. Distinctive in the combination of one discal elytral seta; pronotum cordate and quadrisetose, with posterolateral seta inserted much anterior to obtuse and rounded basal angle, sides straight in basal half, apical bead widely obliterate at middle, lateral bead extended slightly inside base; inner, deep and impunctate, basal sulcus only present; elytral base with a vestigial humeral tooth and a distinct lateral bead, parascutellar striole mostly obliterate; only mesoand metatarsomere 1 indistinctly sulcate; metatrochanteral seta and distal femoral seta vestigial.

DESCRIPTION. Body (Fig. 4), BL 11.2-13.2 mm. Dorsum without iridescence due to superficial yet distinct microsculpture consisting of transverse meshes, very small and moderately transverse on pronotum while narrow on elytra.

Head: Frontal sulci rather shallow, more so (to obliterate) posteriorly. Labrum (sub)sinuate apically.

Pronotum cordate and large, broadest a third from apex; sides rounded in apical two thirds, straight in basal third, PW/ PL 1.07-1.10 (mean 1.08, n=5), PW/HW 1.39-1.43 (1.41). Base truncate, narrower than apex, PB/PA 0.75-0.85 (0.80), basal angles obtuse and rounded; apex evenly sinuate be- 
tween apical angles; these slightly projecting, slightly acute and fairly sharp. Disc convex and smooth, with indistinct or hardly traceable line running inside and parallel to lateral groove; median line fine, slightly deeper at almost indistinct basal and apical transverse impressions, obliterate basally and apically. Basal sulci moderately deep and smooth, running parallel in basal two fifths. Lateral bead fine, extended inside basal sulcus.

Elytra elliptic, broadest medially, EW/EL 1.54-1.63 (1.60), EW/PW 1.13-1.22 (1.18), with an indistinct preapical sinuation, apices rounded separately each, and sides slightly less rounded in basal $1 / 5$ to $2 / 5$. Base long, with a distinct lateral bead inside a vestigial humeral tooth; basal ridge convex slightly apicad, humeral angle obtuse and sharp. Striae deep, impunctate or almost so; intervals slightly convex. Parascutellar striole missing, sometimes vestigial. Discal seta $\mathrm{d} 2$ about $3 / 5$ distant from base. USS: 16 .

Underside smooth, except for mesepisternum moderately and more or less densely punctate, metepisternum and sides of basal three abdominal sternites finely and more sparsely punctate. Prosternal medial groove deep and often slightly broadened anteriorly; prosternal process obtuse and blunt in lateral view, with declivity wide and more or less convex.

Legs: Only meso- and metatarsomere 1 with a blunt lateral carina and a vestigial or no sulcus just above.

Aedeagus (Figs 8-9, 16, 21-22): median lobe distal to basal bulb rounded in cross-section, with apex in dorsal view slightly acute, apically rounded; right margin with a conspicuous tooth just apical to a wide and deep groove which is oblique to the right. Right paramere rounded, hemispherical on right (outer) side and membranous on the reverse. Everted and inflated internal sac (Figs 37-38) dorsal and spiral.

NAME. Toponymic noun referred to Mt. Phang Xi Pang.

DISTRIBUTION. Known from the type locality only, Mt. Phang Xi Pang, northern Vietnam.

HABITATS AND HABITS. The specimens collected by the author were taken under bark of dead trees, standing or not quite fallen, in a cloudy forest.

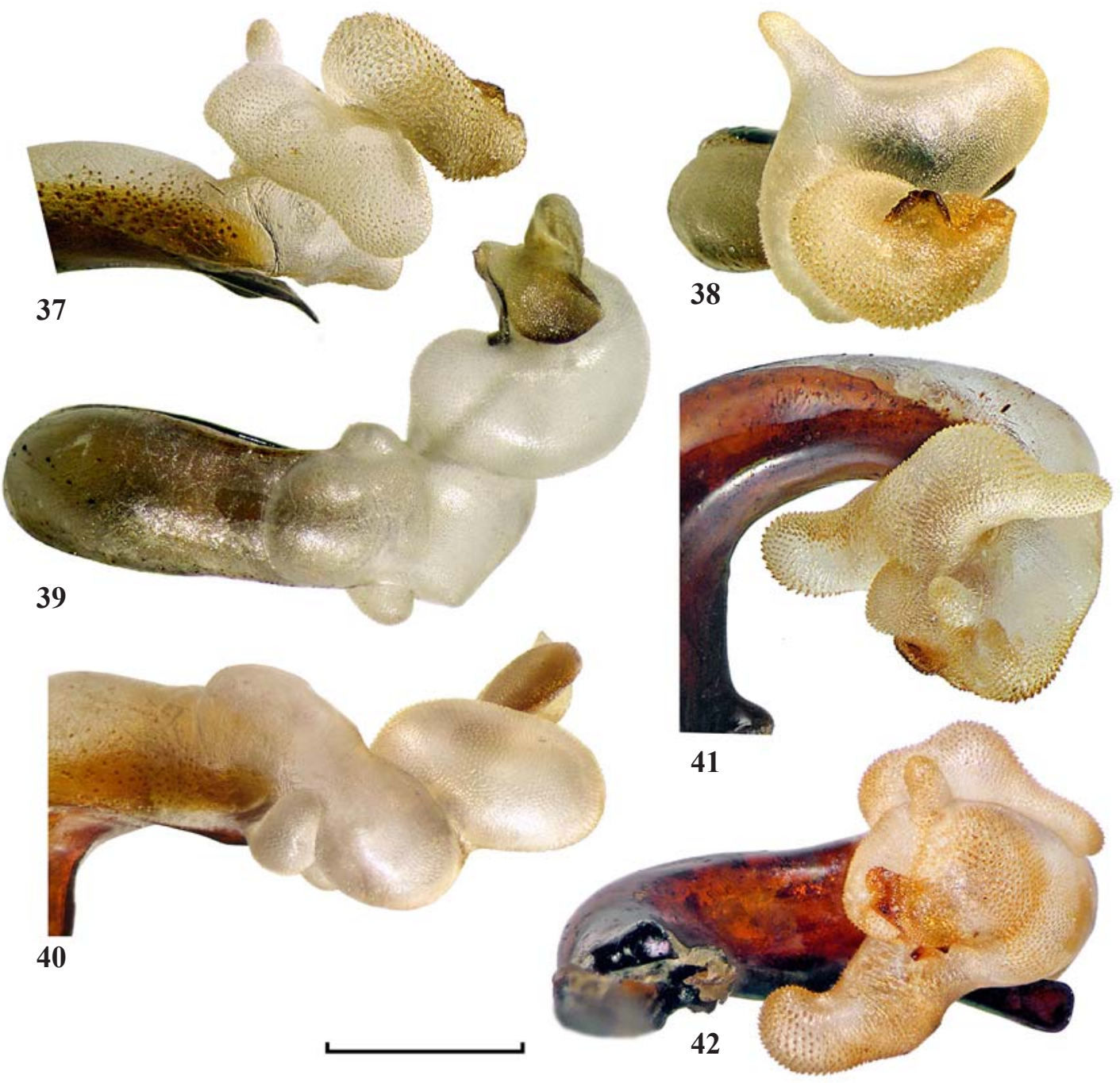

Figs 37-42. Everted and inflated internal sac of aedeagus: 37-38 - Pterostichus phangxipang sp.n.; 39-40 - P. hoanglien sp.n.; 4142 - P. laocaiensis sp.n.; 37, 41 - left view; 38 - dorso-apical view; 39 - dorsal view; 40 - left dorso-apical view; 42 - left ventrolateral view. Scale bar: $1 \mathrm{~mm}$.

Рис. 37-42. Вывернутый и надутый внутренний мешок эдеагуса: 37-38 - Pterostichus phangxipang sp.n.; 39-40 - P. hoanglien sp.n.; 41-42 - P. laocaiensis sp.n.; 37, 41 - слева; 38 - дорзоапикально; 39 - дорзально; 40 - дорзоапикально слева; 42 вентрально слева. Масштаб: 1 мм. 


\section{Pterostichus hoanglien Fedorenko, sp.n.}

Figs 5, 10-11, 19, 28-30, 39-40.

MATERIAL. Holotype $\mathrm{O}^{7}$ (ZMMU) and paratypes (SIEE), $80^{7} \sigma^{7}$, 5 우, labelled: 'N[orthern]-Vietnam, $40 \mathrm{~km} \mathrm{WNW}$ of Lao Cai, env.

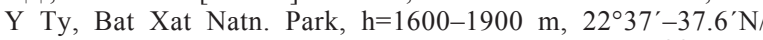
$103^{\circ} 37.3^{\prime}-38.3^{\prime} \mathrm{E}, 16-21 . X .2018$, leg. D. Fedorenko'; 2우, same data, except for $22^{\circ} 36^{\prime} 31^{\prime \prime} \mathrm{N} / 103^{\circ} 37^{\prime} 23^{\prime \prime} \mathrm{E}, \mathrm{h}=2000-2100 \mathrm{~m}, 4$ 14.VI.2019; 2 우, same data except $22^{\circ} 37^{\prime} 36^{\prime \prime} \mathrm{N} / 103^{\circ} 37^{\prime} 32^{\prime \prime} \mathrm{E}$, $\mathrm{h}=1850 \mathrm{~m}$.

DIAGNOSIS. As for the previous species, except that the body is slightly more robust, elytra much more rounded at humeri than behind, with apices truncate combined (i.e., angulate at sutural angles), elytral microsculpture consisting of transverse and very narrow meshes, mesepisterna invisible in dorsal view, pronotum with sublateral line indistinct or hardly traceable, and aedeagus distinctive. For other differences see the description.

DESCRIPTION. As for $P$. phangxipang sp.n. except as follows: Body (Fig. 5), BL 10.4-12 mm. Head: Frontal sulci mostly entire and moderately deep.

Pronotum barely shorter and wider relative to head, PW/ PL 1.12-1.16 (mean 1.14, n=5), PW/HW 1.48-1.52 (1.50), with sides subconvex to indistinctly sinuate in basal third, and base barely wider, PB/PA $0.82-0.88(0.85)$. Apical angles more produced due to apex truncate in between. Disc with fine yet distinct line running inside and parallel to lateral groove; this line being deeper in apical three fifths, very shallow to nearly indistinct behind. Basal sulci slightly shorter, running in basal third. Lateral bead fine and basally extended inside basal sulci.

Elytra barely shorter in general, EW/EL 1.54-1.58 (1.56), EW/PW 1.16-1.22 (1.18), with a nearly indistinct humeral tooth. Parascutellar striole missing. Discal seta d2 1/2-3/5 distant from base. USS: 15-16.

Prosternal process less blunt in lateral view; declivity flat in at least dorsal half.

Aedeagus (Figs 10-11, 19, 28-30): median lobe sharply carinate in basal half of ventral side, with left margin cut in a straight line up to apex; apex rounded at right margin, without preapical tooth or dorsal groove. Right paramere triangular, slightly convex on right side, with thin yet not membranous integument on the reverse. Everted and inflated internal sac (Figs 39-40) dorsal and spiral.

NAME. Toponymic noun, refers to Hoang Lien Mountain Ridge.

DISTRIBUTION. Known from the type locality only, the Bat Xat National Park, northern Vietnam.

HABITATS AND HABITS. The adults were taken under various rotten tree trunks and branches on the ground in cloudy broad-leaved or mixed forests, sometimes under bark of large standing dead trees, at height of more than $2 \mathrm{~m}$ above ground. The fact that the adults of both sexes were frequent in autumn (14 specimens in total), with only four females taken early in summer, may suggest the reproduction period in autumn or in late summer.

\section{Pterostichus batxatensis Fedorenko, sp.n.}

Figs 6, 12-13, 17-18, 23-24, 34-36.

MATERIAL. Holotype $\sigma^{7}$ (ZMMU) and paratypes, $\odot^{7},+$ (SIEE), labelled: 'N-Vietnam, $40 \mathrm{~km}$ WNW of Lao Cai, env. Y Ty, Bat Xat Natn. Park, $h=1600-1900 \mathrm{~m}, 22^{\circ} 37^{\prime}-37.6^{\prime} \mathrm{N} / 103^{\circ} 37.3^{\prime}-38.3^{\prime} \mathrm{E}$, 16-21.X.2018, leg. D. Fedorenko'; $30^{7} 0^{7}, 2$ 우오 , same data, except for $22^{\circ} 36^{\prime} 31^{\prime \prime} \mathrm{N} / 103^{\circ} 37^{\prime} 23^{\prime \prime} \mathrm{E}, \mathrm{h}=2000-2100 \mathrm{~m}, 4-14 . V I .2019$.

DIAGNOSIS. As for $P$. phangxipang sp.n., except for pronotal posterolateral seta missing and aedeagus distinctive. For additional differences see description.
DESCRIPTION. Body (Fig. 6), BL 12.4-13.5 mm.

Pronotum: PW/PL 1.04-1.13 (mean 1.08, $\mathrm{n}=3$ ), PW/HW $1.40-1.48$ (1.44), PB/PA 0.79-0.88 (0.82). Apical bead entire to interrupted just medially.

Elytra more rounded at humeri than behind, EW/EL 1.59-1.64 (1.62), EW/PW 1.14-1.18 (1.16); apices truncate combined to rounded separately each. Humeral tooth indistinct. Parascutellar striole missing or vestigial (entire unilaterally in the holotype). USS: 16-17.

Legs: distal metafemoral seta vestigial or missing.

Aedeagus (Figs 12-13, 17-18, 23-24): median lobe with apex widely rounded. Right paramere short (lost through mounting). Everted and inflated internal sac (Figs 34-36) dorsal and spiral, combined with a large horn emerged from dorsal membrane of median lobe.

NAME. Refers to the type locality of the species.

DISTRIBUTION. Known from the type locality only, the Bat Xat National Park, northern Vietnam.

HABITATS AND HABITS. All specimens were hand collected under fragments of rotten tree trunks on the ground or under bark of rotten tree trunks tilted at an angle in a cloudy mixed forest.

\section{Pterostichus laocaiensis Fedorenko, sp.n.}

Figs 7, 14-15, 20, 26-27, 41-42.

MATERIAL. Holotype $\sigma^{7}$ (ZMMU) and paratype $\sigma^{7}$ (SIEE), labelled: 'N Vietnam, Lao Cai Prov., Hoang Lien Son Mt. Ridge, env. Fansipan [=Phahg Xi Pang] Mt, Tram Ton, h=1950-2100 [m], 15-30.VII.2007, leg. D. Fedorenko'.

DIAGNOSIS. As for P. phangxipang sp.n., except for pronotal posterolateral seta missing, body slender, pronotum barely longer than wide and subsinuate on sides in basal half, pronotal and elytral microsculpture consisting of dense transverse lines; elytral basolateral bead missing, parascutellar striole entire; meso- and metatarsomeres 1-3 carinate and sulcate laterally; distal femoral seta missing. For additional differences see description.

DESCRIPTION. Body slender (Fig. 7), BL 13-13.2 mm.

Head: Frontal sulci straight and slightly diverging. Labrum sinuate apically.

Pronotum very slender, broadest two fifths from apex, barely longer than wide, PW/PL 0.93-0.97, PW/HW 1.281.35 , with sides subsinuate before base. Base subconvex to truncate, $\mathrm{PB} / \mathrm{PA}$ 0.81-0.85; apex subconvex to truncate between slightly projecting apical angles, with apical bead entire or interrupted just medially. Disc with indistinct basal and apical transverse impressions; median line fine and nearly entire, ill-defined basally and almost reaching apex; sublateral line missing. Basal sulci $\gamma$-shaped combined, inner long, running in basal two fifths and S-shaped, anteriorly parallel, then diverging and afterwards incurved just in front of base; outer sulcus vestigial, very short and shallow, running close to lateral bead. Lateral bead obliterate just in front of basal angle.

Elytra oblong, EW/EL 1.78-1.80, EW/PW 1.26-1.33, broadest three fifths from base, with an indistinct preapical sinuation, apices truncate combined or rounded separately each. Base long, with lateral bead obliterate; humeral tooth vestigial. Intervals convex. Discal seta d2 about 3/5 distant from base. USS: 16-17.

Prosternal process with posterior declivity convex, narrow and subcostate at medial constriction.

Aedeagus (Figs 14-15, 20, 26-27): median lobe ventrally carinate in basal half, with a convex ridge in middle third of right ventrolateral margin; apex in dorsal view fairly long, parallel-sided, rounded apically, with a shallow groove that is 
oblique to the right. Everted and inflated internal sac (Figs 41-42) bent to the left and then ventrad.

NAME. Refers to Lao Cai Province, Vietnam, from where the species is described.

DISTRIBUTION. Known from the type locality only, Mt. Phang Xi Pang, northern Vietnam.

HABITATS AND HABITS. The species was hand collected under bark of a not quite fallen dead tree in a cloudy forest.

Acknowledgements. This study was funded by the Presidium of the Russian academy of sciences, Program No.41 "Biodiversity of natural systems and biological resources of Russia".

\section{References}

Allegro G., Sciaky R. 2010. Review of the Chinese subgenus Circinatus of Pterostichus, with description of six new species (Coleoptera, Carabidae) // Boll. Mus. Stor. Nat. Verona. Vol.34. Bot. \& Zool. P.3-18.

Sciaky R. 1996. Circinatus new subgenus and three new species of Pterostichus from China (Coleoptera Carabidae) // Ann. Mus. Sci. Nat. Brescia. 1994. Vol.30. P.217-231.

Sciaky R. 1997. New subgenera and new species of Pterostichini from China (Coleoptera, Carabidae) // Boll. Mus. Stor. Nat. Venezia. 1996. Vol.47. P.153-176.

Sciaky R., Allegro G. 2010. Two new subgenera and two new species of Pterostichus from China (Coleoptera, Carabidae) // Boll. Mus. Stor. Nat. Verona. Vol.37. Bot. \& Zool. P.113-122.

Shi H., Liang H. 2015. The genus Pterostichus in China II: the subgenus Circinatus Sciaky, a species revision and phylogeny (Carabidae, Pterostichini) and new species descriptions // Zookeys. Vol.536. P.1-92. 